ISLAMIC BANKING: Jurnal Pemikiran dan Pengembangan Perbankan Syariah, Volume 6 Nomor 1 Edisi Agustus 2020 | 1

\title{
TINJAUAN ATAS IMPLEMENTASI PERPANJANGAN MASA ANGSURAN UNTUK PEMBIAYAAN DI BANK SYARIAH PADA SITUASI PANDEMI COVID-19
}

\author{
Muhammad Ubaidillah \\ Universitas Diponegoro Semarang \\ Email: ubaidillah@lecturer.undip.ac.id \\ Rizqon Halal Syah Aji \\ Universitas Islam Negeri Syarif Hidayatullah Jakarta \\ Email: rizqon.halal@uinjkt.ac.id
}

\begin{abstract}
Covid-19 pandemic has occurred in almost all countries in the world. The pandemic has caused millions of people to find it difficult to pay off credit or financing installments due to declining daily income. If these conditions are not properly addressed, it will cause a country's economic growth to decline. This article aims to examine the application of the Surah Al Baqarah verse 280 to the granting of credit or financing restructuring to debtors affected by the Covid-19 pandemic. The literature review method is used in this article. In addition, this article also uses descriptive analysis methods to describe the phenomena that occur in the field. The study conducted in this article shows that the application of Surah Al Baqarah verse 280 at the time of the Covid-19 pandemic can be a solution to maintain Indonesia's economic growth rate.
\end{abstract}

Keywords: Covid-19, Surah Al Baqarah verse 280, Restructuring of Credit or Financing, Economic Growth, Liquidity

\begin{abstract}
Abstrak
Pandemi Covid-19 telah terjadi di hampir seluruh negara di dunia. Pandemi tersebut telah mengakibatkan jutaan orang mengalami kesulitan untuk melunasi angsuran kredit atau pembiayaan karena menurunnya penghasilan sehari-hari. Jika kondisi tersebut tidak disikapi dengan baik maka akan menyebabkan menurunnya pertumbuhan ekonomi suatu negara. Artikel ini bertujuan untuk mengkaji penerapan Alquran Surat Al Baqarah ayat 280 terhadap pemberian restrukturisasi kredit atau pembiayaan kepada debitur yang terdampak pandemi Covid-19. Metode kajian pustaka digunakan dalam artikel ini. Selain itu, artikel ini juga menggunakan metode analisis deskriptif untuk menggambarkan fenomena yang terjadi di lapangan. Kajian yang dilakukan dalam artikel ini menunjukkan bahwa penerapan Surat Al Baqarah ayat 280 pada saat pandemi Covid-19 dapat menjadi solusi untuk mempertahankan tingkat pertumbuhan ekonomi Indonesia.
\end{abstract}

Kata Kunci : Covid-19, Surah Al Baqarah ayat 280, Restrukturisasi Kredit atau Pembiayaan, Pertumbuhan Ekonomi, Likuiditas 


\section{2 | Muhammad Ubaidillah, Rizqon Halal Syah Aji, TINJAUAN ATAS IMPLEMENTASI PERPANJANGAN......}

\section{Dasar Pemikiran}

Islam telah mengatur urusan utang piutang dengan ketat dan tegas. Islam secara prinsip menggariskan bahwa hukum meminjam uang atau berutang itu mubah, sedangkan melunasi utang berhukum wajib. Orang yang meminjam uang atau debitur wajib melunasi utang dalam waktu yang telah disepakati oleh kedua belah pihak (kreditur dan debitur). Tidak dipungkiri, sering terjadi kondisi penangguhan pelunasan utang ketika debitur mengalami kesulitan dalam melunasi pinjamannya. Kesulitan membayar utang sering terjadi dan menimpa siapapun debitur. Kondisi ini bisa terjadi dikarenakan kondisi keuangan yang sulit, baik dari segi usaha maupun faktor lain yang menyebabkan debitur mengalami kesulitan keuangan. Kondisi kesulitan keuangan debitur, menstimulasi pihaknya harus mengulang kesepakatan baru agar dapat menunda pembayaran utangnya. Keadaan tersebut banyak dijumpai ketika terjadi krisis ekonomi, terlebih pada saat sekarang, ketika wabah Pandemi global Covid-19 menghancurkan sendi-sendi ekonomi negara yang berdampak pada sulitnya ekonomi masyarakat.

Dampak global Pandemi Covid-19 telah menyerang 216 negara di dunia dengan jumlah kasus yang terkonfirmasi sebanyak 9.413.289 jiwa dan mengakibatkan sebanyak 482.730 orang meninggal dunia (www.covid19.go.id; Suryahadi et al 2020). Kondisi korban Pandemi di Indonesia terkonfirmasi sebanyak 51.427 jiwa terkategori positif terkena virus dan 2.683 jiwa telah meninggal (World Health Organization 2020). Menurut laporan WHO angka ini akan terus meningkat dari hari ke hari. Sebagai upaya penanganan atas wabah tersebut, pemerintah Indonesia telah melakukan tindakan khususnya bagi wilayah yang terpapar Pandemi untuk melakukan tindakan Pembatasan Sosial Berskala Besar (PSBB) dan mengatur cara bekerja maupun beraktivitas seharihari dari rumah (work from home). Namun, tidak semua pekerjaan dapat dilakukan dari rumah, seperti halnya pekerjaan pada sektor informal seperti para pedagang usaha mikro kecil menengah (UMKM) ataupun usaha pada sektor jasa seperti jasa perdagangan, jasa pertanian dan lain-lain. Akibatnya dampak Pandemi tersebut, jutaan warga yang bekerja di sektor informal bahkan juga sektor formal terpaksa kehilangan pekerjaan, dan berdampak pada menurunnya penghasilan. 
ISLAMIC BANKING: Jurnal Pemikiran dan Pengembangan Perbankan Syariah, Volume 6 Nomor 1 Edisi Agustus $2020 \mid 3$

Menurunnya pendapatan masyarakat berdampak pada tingkat konsumsi, sehingga berpengaruh pada kontraksi pertumbuhan ekonomi. Pemerintah sebagai regulator ekonomi mempunyai peran penting dalam menetapkan kebijakan penyelamatan ekonomi masyarakat karena dampak Pandemi global Covid-19. Secara syari’i, Islam memberikan payung hukum terhadap solusi permasalahan perekonomian. Alquran Surat Al Baqarah ayat 280 menjelaskan "Dan jika (orang yang berutang itu) dalam kesulitan, maka berilah tenggang waktu sampai dia memperoleh kelapangan. Dan jika kamu menyedekahkan (sebagian atau semua utang), itu lebih baik bagimu, jika kamu mengetahui." Uraian dari QS. Al Baqarah (280), sangat relevan ketika dihubungkan dengan kondisi kesulitan ekonomi masyarakat karena dampak Pandemi Covid-19. Kondisi ekonomi masyarakat mengalami kesulitan besar akibat kebijakan pemerintah Indonesia yang memaksa memutus rantai Pandemi virus Covid-19. Kebijakan yang diambil antara lain seperti physical distancing, social distancing, dan terakhir adalah kebijakan Pembatasan Sosial Berskala Besar (PSBB). Kesulitan ekonomi bukan sematamata dialami oleh penduduk Indonesia, melainkan oleh penduduk dunia secara global (Nurhayati \& Aji 2020). Relevansi surat Al Baqarah 280 dengan kebijakan ekonomi keuangan pemerintah Indonesia diharapkan dapat mengatasi masalah yang melilit para pengguna jasa keuangan, sehingga mereka dapat keluar dari kesulitan keuangan.

Respons Pemerintah sebagai upaya mengatasi krisis keuangan pada kondisi Pandemi dilakukan dengan mengeluarkan regulasi atas pengaturan keuangan negara. Ada dua regulasi keuangan negara yang dikeluarkan oleh negara untuk mengatur pembiayaan keuangan bagi masyarakat. Dua aturan tersebut yaitu Peraturan Pemerintah Pengganti Undang-Undang (Perppu) Nomor 1 Tahun 2020 dan Peraturan Otoritas Jasa Keuangan (POJK) Nomor 11/POJK.03/2020. Perppu Nomor 1 Tahun 2020 pada tanggal 18 Mei 2020 telah meningkat status hukumnya menjadi Undang-Undang Nomor 2 Tahun 2020. Kedua aturan tersebut telah menjadi payung hukum pemberlakuan restrukturisasi kredit atau pembiayaan bagi debitur yang terdampak Pandemi Covid-19 (Republik Indonesia 2020; Otoritas Jasa Keuangan 2020).

Regulasi dari dua payung hukum tersebut belum terlihat dampaknya untuk masyarakat. Masih banyak debitur yang mengalami penurunan penghasilan karena P-ISSN : 2460-9595 


\section{4 | Muhammad Ubaidillah, Rizqon Halal Syah Aji, TINJAUAN ATAS IMPLEMENTASI PERPANJANGAN......}

dampak Pandemi belum merasakan kemudahan dari berlakunya dua payung hukum tersebut. Malah sebaliknya, banyak debitur mengalami kesulitan dalam proses pengurusan restrukturisasi kedit atau pembiayaan di lembaga keuangan serta masih diharuskan untuk membayar beban angsuran seperti biasa (Bisnis.com 2020a; Kompas 2020). Kebijakan hukum yang diambil oleh pemerintah belum dapat dinikmati secara cepat dan menyeluruh oleh debitur. Jika kondisi tersebut masih berlangsung terus dengan jangka waktu lama, maka akan memberikan pengaruh kuat terhadap penurunan pertumbuhan ekonomi Indonesia.

Latar belakang pemikiran dari kajian ini telah mengeksplorasi hubungan kuat antara kebijakan pemerintah Indonesia atas regulasi keuangan di Indonesia dengan perintah Allah Swt pada surat Al Baqarah 280. Dua payung hukum yang telah disahkan oleh pemerintah mengisyaratkan pertanyaan, efektifkah pelaksanaan kebijakan dari Undang-Undang Nomor 2 Tahun 2020 dan Peraturan Otoritas Jasa Keuangan (POJK) Nomor 11/POJK.03/2020? Kajian ini menjadi sangat relevan dan penting ketika kebijakan hukum mengenai jasa keuangan telah disahkan oleh pemerintah, maka perlu adanya publikasi serta evaluasi, untuk melihat sejauh mana efektifnya kebijakan tersebut pada sisi regulasi sehingga dapat dinikmati oleh masyarakat.

\section{Metode Penelitian}

Penelitian ini menggunakan studi pustaka (library research) dengan metode penelitian deskriptif ekplanatori (Sugiyono 2012). Penelitian ini bertujuan untuk mendeskriptifkan fenomena yang seperti halnya perbedaan situasi kondisi karena kebijakan-kebijakan tertentu yang telah diambil oleh invidu atau kelompok orang atau bahkan institusi. Penelitian ini mendalami tentang kebijakan pemerintah Indonesia mengenai Undang-Undang Nomor 2 Tahun 2020 dan Peraturan Otoritas Jasa Keuangan (POJK) Nomor 11/POJK.03/2020 yang direlasikan dengan kandungan Alquran surat Al Baqarah ayat 280. Kumpulan data yang berkembang seputar pemberitaan atas kebijakan keuangan yang diambil oleh pemerintah karena Pandemi Covid-19 bersumber dari buku, naskah undang-undang, peraturan OJK, artikel jurnal, serta artikel berita yang dikumpulkan dan dirumuskan menjadi suatu konsep yang utuh dan sistematis. 
ISLAMIC BANKING: Jurnal Pemikiran dan Pengembangan Perbankan Syariah, Volume 6 Nomor 1 Edisi Agustus 2020

\section{Ulasan Teori \\ Jenis Utang}

Utang dibagi menjadi tiga jenis yaitu utang konsumtif, utang produktif dan utang negara (Rahim, Suliaman, and Razzak 2012). Utang konsumtif adalah utang yang diambil dengan tujuan untuk konsumsi semata. Umumnya jenis utang ini merupakan utang yang dilakukan oleh golongan menengah ke bawah. Utang produktif adalah utang yang diambil untuk keperluan usaha baik oleh perorangan maupun korporasi. Utang produktif biasanya dilakukan untuk meningkatkan produktivitas dari suatu usaha. Sementara, utang negara adalah utang yang dilakukan oleh pemerintah. Utang negara biasanya digunakan untuk keperluan pembangunan atau untuk menutup defisit anggaran negara. Artikel ini hanya membahas jenis utang yang pertama dan kedua yaitu utang konsumtif dan utang produktif. Sementara utang negara tidak dijelaskan lebih lanjut dalam artikel ini.

Masyarakat golongan menengah ke bawah merupakan golongan yang banyak terlibat dalam utang konsumtif. Penghasilan yang didapatkan dari keluarga golongan menengah ke bawah hanya cukup untuk memenuhi kebutuhan hidup sehari-hari. Kebutuhan lain yang sifatnya bukan pengeluaran sehari-hari seperti tempat tinggal dan kendaraan biasanya dicukupkan dengan cara berutang baik kepada perorangan maupun lembaga keuangan bank dan nonbank (Aji 2014). Bahkan sudah lazim pola pikir yang beredar di masyarakat seperti misalnya jika tidak melalui utang maka bagaimana mereka bisa mempunyai rumah ataupun kendaraan. Lembaga keuangan pun menyambut baik pikiran tersebut dengan banyak menyediakan berbagai jenis utang baik kredit dari lembaga keuangan konvensional maupun pembiayaan dari lembaga keuangan Syariah (Aji and Kurniasih 2015). Prinsip utang untuk memenuhi kebutuhan pokok tersebut adalah boleh sepanjang tidak melanggar syariat seperti tidak berutang yang bersifat ribawi dan berutang sesuai dengan kemampuan untuk membayar kembali. Namun, jika dua hal tersebut dilanggar, akan menimbulkan ketidakberkahan dalam harta yang didapatkan serta akan senantiasa terbelenggu dalam lingkaran utang piutang yang tidak berkesudahan. 


\section{6 | Muhammad Ubaidillah, Rizqon Halal Syah Aji, TINJAUAN ATAS IMPLEMENTASI PERPANJANGAN......}

\section{Tafsir Ekonomi dari Surat Al Baqarah Ayat 280}

Allah telah berfirman dalam Alquran Surat Al Baqarah ayat 280,

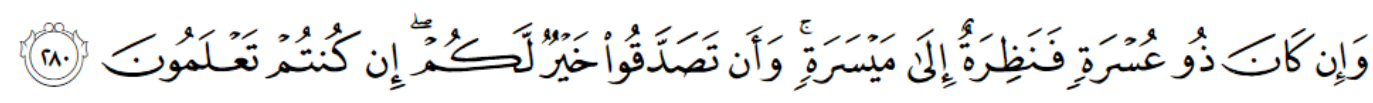

Artinya:

Dan jika (orang yang berutang itu) dalam kesulitan, maka berilah tenggang waktu sampai dia memperoleh kelapangan. Dan jika kamu menyedekahkan (sebagian atau semua utang), itu lebih baik bagimu, jika kamu mengetahui.

Surat Al Baqarah ayat 280 merupakan ayat yang lebih menjelaskan anjuran atas kearifan kreditur atau orang yang memberi pinjaman uang. Allah memerintahkan para kreditur untuk bersabar dengan cara memberi kelonggaran waktu bagi debitur yang mengalami kesulitan membayar dan tidak menemukan apa yang bisa digunakan untuk melunasi utangnya. Kelonggaran waktu tersebut harus tidak menambah jumlah utang yang seharusnya karena itu termasuk riba yang dilarang dalam Islam. Perilaku menambah jumlah utang yang harus dibayar karena pemberian tambahan tempo pembayaran dinamakan riba jahiliyah karena merupakan perilaku yang lazim dilakukan oleh masyarakat jahiliyah sebagaimana yang dijelaskan oleh Ibnu Katsir dalam tafsirnya (Katsir 2004).

Senada dengan Imam Ibnu Katsir, Imam Al-Qurtubi juga menerangkan asbabun nuzul tentang turunnya ayat tersebut. Dalam keterangannya, bahwa ayat ini turun ketika Bani Tsaqif menuntut pelunasan utang dari Bani al-Mughirah. Bani al-Mughirah meminta kelonggaran waktu untuk membayar sampai buah-buahan mereka bisa dipanen. Namun, Bani Tsaqif tidak menerima permintaan tersebut sehingga turunlah Surat Al Baqarah ayat 280 (Al-Qurtubi 2006).

Meskipun Alquran menganjurkan kreditur untuk memberi kelapangan bagi debitur yang kesulitan dalam melunasi utangnya, Alquran tidak memberi rincian definisi kesulitan tersebut. Surat Al Baqarah ayat 280 hanya memberikan panduan secara umum mengenai kondisi kesulitan yang dialami oleh debitur. Ab Rahim, Suliaman dan Abd Razzak (2012) memberikan tiga kriteria kesulitan yang membolehkan implementasi ayat tersebut. Pertama, ketika orang mempunyai beban dalam kehidupannya, untuk mengatasi hidupnya maka ia berutang, dengan utangnya 
ISLAMIC BANKING: Jurnal Pemikiran dan Pengembangan Perbankan Syariah, Volume 6 Nomor 1 Edisi Agustus $2020 \mid 7$

maka ia kemudian mampu mengatasi beban keuangan yang menimpanya. Kedua, orang miskin yang melalui utang menjadikannya mampu meneruskan kehidupannya. Ketiga, orang yang terkena musibah sehingga harta bendanya habis. Ketika ia berutang dan membuatnya bisa memperoleh harta untuk meneruskan kehidupannya kembali.

Islam tidak membiarkan debitur berketerusan berada dalam situasi sulit dalam melunasi utang. Penegasan pada QS Al Baqarah (280), menyerukan kepada kreditur untuk menyedekahkan sebagian atau seluruh utang yang diberikan kepada debitur ketika kreditur melihat kondisi ketidakmampuan jangka panjang debitur dalam melunasi utangnya. Tentu, ayat tersebut, dilarang untuk dijadikan alasan bagi debitur untuk berlindung dari kewajiban pelunasan utang. Hukum Islam sangat mengatur pentingnya kewajiban membayar utang oleh debitur. Bahkan hukum Islam menganalogikan terhadap debitur ketika tidak membayar utang dengan seorang pencuri. Rasulullah Saw pernah menyampaikan dalam hadis yang dapat diartikan sebagai berikut; "Siapa saja yang berutang lalu berniat tidak mau melunasinya, maka dia akan bertemu Allah (pada hari kiamat) dalam status sebagai pencuri" (HR. Ibnu Majah No. 2410). Sebaliknya diriwayatkan oleh Ibnu Majah pada Hadis nomor 2399, Allah swt akan memudahkan debitur dalam melunasi utangnya sepanjang mau berupaya melunasinya.

Selain anjuran untuk menyedekahkan piutang, Islam mengkategorikan debitur yang kesulitan dalam melunasi utang kedalam kelompok mustahik (kelompok orang yang berhak menerima zakat). Perkara ini ditegaskan dalam Alquran Surat At Taubah ayat 60 ;

Sesungguhnya zakat itu hanyalah untuk orang-orang fakir, orang miskin, amil zakat, yang dilunakkan hatinya (mualaf), untuk (memerdekakan) hamba sahaya, untuk (membebaskan) orang yang berutang, untuk jalan Allah dan untuk orang yang sedang dalam perjalanan, sebagai kewajiban dari Allah. Allah Maha Mengetahui, Mahabijaksana. QS At Taubah (60).

Ayat pada QS At Taubah (60), menjelaskan bahwa debitur berhak atas pemberian zakat sampai dirinya berada dalam kelapangan untuk melunasi utangnya. Akan tetapi, ayat tersebut tidak merinci tentang batasan seorang debitur yang kondisinya dianggap mempunyai kelapangan hidup. Oleh karena itu, definisi ini diserahkan kepada situasi 


\section{8}

Muhammad Ubaidillah, Rizqon Halal Syah Aji, TINJAUAN ATAS IMPLEMENTASI PERPANJANGAN......

masyarakat dengan acuan Ijma' maupun Qiyas (Ab Rahim, Suliaman, and Abd Razzak 2012).

\section{Pembahasan}

\section{Regulasi Pembiayaan Keuangan dan Pesan Alquran Surat Al Baqarah Ayat 280}

Penekanan Undang-Undang Nomor 2 Tahun 2020 yaitu memerintahkan kepada institusi perbankan untuk memberikan kelonggaran kepada debitur. Berlakunya payung hukum tersebut berdampak pada regulasi bank umum baik sistemik maupun tidak sistemik mengalami kesulitan keuangan. Konsekuensi yang terjadi dari kebijakan tersebut, maka pemerintah memberikan kewenangan kepada Bank Indonesia untuk memberikan pinjaman likuiditas jangka pendek atau pembiayaan likuiditas jangka pendek kepada bank. Jika stimulus tersebut belum berhasil menyelamatkan keadaan, maka Bank Indonesia diberi kewenangan untuk memberikan pinjaman likuiditas khusus kepada bank sistemik. Pasal-pasal yang menjadi dasar kebijakan tersebut dijelaskan pada pasal 16 ayat 1 poin a dan b seperti yang tertulis pada paragraf berikut ini;

Untuk mendukung pelaksanaan kewenangan KSSK (Komite Stabilitas Sistem Keuangan) dalam rangka penanganan permasalahan stabilitas sistem keuangan sebagaimana dimaksud dalam Pasal 15 ayat (1), Bank Indonesia diberikan kewenangan untuk:

a. Memberikan pinjaman likuiditas jangka pendek atau pembiayaan likuiditas jangka pendek berdasarkan prinsip syariah kepada Bank Sistemik atau bank selain Bank Sistemik;

b. Memberikan Pinjaman Likuiditas Khusus kepada Bank Sistemik yang mengalami kesulitan likuiditas dan tidak memenuhi persyaratan pemberian pinjaman likuiditas jangka pendek atau pembiayaan likuiditas jangka pendek berdasarkan prinsip syariah yang dijamin oleh Pemerintah dan diberikan berdasarkan Keputusan KSSK;

Penjelasan pasal 16 ayat 1 point a dan b sangat jelas secara operasional bagi perbankan. Meskipun sebelum Perppu nomor 1 tahun 2020 disahkan menjadi undangundang tersebut, OJK telah mengeluarkan peraturan OJK nomor 11/POJK.03/2020 tentang stimulus perekonomian nasional sebagai Countercyclical dampak ekonomi akibat penyebaran Coronavirus Disease 2019. Kebijakan Countercyclical adalah kebijakan yang berlawanan dengan arus siklus bisnis. Contoh penerapannya ketika P-ISSN : 2460-9595 
terjadi resesi ekonomi, pemerintah menetapkan kebijakan ekspansif seperti melonggarkan fiskal dan moneter (Kaminsky, Reinhart, and Végh 2004). Dalam kondisi ini, kebijakan yang diambil adalah kebijakan untuk merestrukturisasi kredit atau pembiayaan bagi debitur yang mengalami kesulitan akibat pandemi Covid-19. OJK mengimbau bagi bank untuk memberikan restrukturisasi terhadap kredit atau pembiayaan kepada debitur yang terkena dampak ekonomi akibat Pandemi Covid-19 dari sektor usaha mikro, kecil dan menengah tanpa batasan plafon pinjaman. Sebagaimana dijelaskan undang-undang nomor 2 tahun 2020 juga menyebutkan pada pasal 2 ayat 2 , pasal 5 ayat 2 serta pasal 6 poin b berikut ini.

Pasal 2 ayat 2: Kebijakan yang mendukung stimulus pertumbuhan ekonomi sebagaimana dimaksud pada ayat (1) meliputi:

a. kebijakan penetapan kualitas aset; dan

b. kebijakan restrukturisasi kredit atau pembiayaan.

Pasal 5 ayat 2: Restrukturisasi kredit atau pembiayaan sebagaimana dimaksud pada ayat (1) dapat dilakukan terhadap kredit atau pembiayaan yang diberikan sebelum maupun setelah debitur terkena dampak penyebaran coronavirus disease 2019 (COVID-19) termasuk debitur usaha mikro, kecil, dan menengah.

Pasal 6: Ketentuan sebagaimana dimaksud dalam Pasal 5 berlaku untuk kredit atau pembiayaan yang memenuhi persyaratan:

b. direstrukturisasi setelah debitur terkena dampak penyebaran coronavirus disease 2019 (COVID-19) termasuk debitur usaha mikro, kecil, dan menengah.

Kebijakan yang telah dikeluarkan oleh pemerintah Indonesia melalui UU Nomor 2 Tahun 2020 dan POJK Nomor 11/POJK.03/2020 yang memberi kelonggaran pada debitur yang mengalami kesulitan akibat pandemi Covid-19 telah relevan dengan perintah dalam QS Al Baqarah (280). Meskipun secara implementasi di lapangan belum semuanya sesuai dengan harapan kebijakan pemerintah. Masih banyak dikeluhkan debitur karena belum mendapatkan fasilitas restrukturisasi kredit atau pembiayaan (CNBC 2020; Bisnis.com 2020a; Kompas 2020). Kondisi tersebut distimulasi oleh pemberlakuan kebijakan lain dalam mencegah penyebaran Pandemi Covid-19, yakni kebijakan bekerja dari rumah (WFH) yang berakibat melambatnya proses verifikasi 
10 Muhammad Ubaidillah, Rizqon Halal Syah Aji, TINJAUAN ATAS IMPLEMENTASI PERPANJANGAN...... prosedural di masing-masing perbankan (Kumparan 2020). Selain itu, keputusan restrukturisasi kredit atau pembiayaan diserahkan kepada masing-masing bank, sehingga berdampak pada perbedaan kebijakan antarbank (Bisnis.com 2020b). Oleh karena itu, pemerintah melalui OJK harus lebih transparan dan tegas dalam mengakomodasi keluhan debitur yang terdampak Covid-19 yang belum ditindaklanjuti oleh perbankan.

\section{Dampak Ekonomi dan Ghirah Alquran Surat Al Baqarah Ayat 280}

Pandemi Covid-19 berdampak pada situasi ekonomi Indonesia. Menurut data Kementerian Tenaga Kerja (Kemnaker) pada tanggal 2 Juni 2020 terdapat 3,05 juta orang pekerja mengalami pemutusan hubungan kerja/PHK. Jumlah tersebut akan terus meningkat jika keadaan semakin memburuk. Bahkan, Lembaga Ilmu Pengetahuan Indonesia (LIPI), Badan Litbang Ketenagakerjaan Kemnaker dan Lembaga Demografi Fakultas Ekonomi dan Bisnis Universitas Indonesia memprediksi ada sebanyak 25 juta pekerja yang terancam kehilangan pekerjaan terutama dari sektor pekerjaan bebas (Tempo.co 2020).

Dampak ekonomi akibat pemutusan kerja tersebut berpengaruh terhadap pendapatan nasional. Secara teoritikal maupun empirikal, pendekatan pendapatan nasional yang sesuai dengan kondisi PHK adalah pendekatan pengeluaran. Pendekatan pengeluaran merupakan metode perhitungan pendapatan nasional dengan cara menjumlahkan seluruh pengeluaran atau perbelanjaan atas barang dan jasa yang diproduksi di dalam suatu negara (Sukirno 2011). Secara matematis, pendekatan pengeluaran dinotasikan dalam persamaan $Y=C+I+G+(X-M)$. Dari persamaan tersebut dapat diketahui bahwa pendapatan nasional $(\mathrm{Y})$ merupakan penjumlahan secara agregat dari konsumsi (C), investasi (I), pengeluaran pemerintah (G), Ekspor (X) dikurangi Impor (M).

Ketika terjadi Pandemi Covid-19 dan kebijakan bekerja dari rumah serta PSBB, maka berdampak pada jutaan tenaga kerja harus bekerja dari rumah, tingkat pendapatan berkurang, bahkan yang terburuk adalah sebanyak 3,05 juta pekerja mengalami PHK (Tempo.co 2020). Kejadian itu semua berdampak secara ekonomi yaitu penurunan daya 
beli masyarakat. Kondisi tersebut diperparah oleh situasi para debitur yang menerima dampak dari rendahnya konsumsi masyarakat. Dampak yang nyata adalah kewajiban mengangsur cicilan kredit atau pembiayaan menjadi terganggu (macet). Terganggunya pembayaran angsuran kredit atau pembiayaan kepada bank atau pun kreditur berdampak langsung pada menurunkan tingkat konsumsi masyarakat dibandingkan saat sebelum terjadinya pandemi Covid-19.

Adanya penurunan konsumsi masyarakat akibat penurunan penghasilan serta masih adanya kewajiban untuk membayar angsuran selama masa Pandemi Covid-19 akan mengakibatkan penurunan tingkat pertumbuhan ekonomi. Meskipun penulis belum menemukan analisis korelasi langsung antara kedua hal tersebut selama masa Pandemi Covid-19, sudah ada peneliti yang menganalisis korelasi antara tingkat konsumsi dengan pertumbuhan ekonomi khususnya dalam perspektif negara Indonesia. Swaramarinda dan Indriani pada tahun 2011 telah menganalisis korelasi konsumsi dan pengeluaran pemerintah terhadap pertumbuhan ekonomi Indonesia. Data yang dianalisis adalah data sekunder tahunan selama 11 tahun sejak tahun 1997 hingga tahun 2007. Hasil dari analisis data yang telah dilakukan membuktikan bahwa ada korelasi yang positif antara pengeluaran konsumsi pemerintah dengan pertumbuhan ekonomi pada periode penelitian. Hal tersebut bisa berlaku karena pengeluaran konsumsi pemerintah yang terdiri dari belanja pegawai yang meliputi gaji pegawai, uang pensiun, tunjangan dan belanja barang-barang dalam negeri, dana rutin daerah serta pengeluaran rutin lainnya akan meningkatkan konsumsi pegawai atau masyarakat terhadap barang dan jasa (Swaramarinda and Indriani 2011).

Penelitian serupa dilakukan oleh Ernita, Amar dan Syofyan pada tahun 2013 yang menganalisis pertumbuhan ekonomi, konsumsi dan investasi di Indonesia. Data yang digunakan adalah data sekunder kuartalan selama 10 tahun mulai dari kuartal I tahun 2001 sampai dengan kuartal IV tahun 2010. Hasil dari analisis yang telah dilakukan membuktikan bahwa variabel konsumsi, investasi, pengeluaran pemerintah, dan net ekspor (ekspor dikurangi impor) secara bersama-sama berpengaruh signifikan terhadap pertumbuhan ekonomi di Indonesia. Sedangkan secara parsial, baik konsumsi, investasi, pengeluaran pemerintah, maupun net ekspor berpengaruh signifikan dan positif terhadap P-ISSN : 2460-9595 


\section{2 | Muhammad Ubaidillah, Rizqon Halal Syah Aji, TINJAUAN ATAS IMPLEMENTASI PERPANJANGAN......}

pertumbuhan ekonomi di Indonesia. Hasil penelitian tersebut mempunyai arti jika terjadi kenaikan variabel-variabel independen yang meliputi konsumsi, investasi, pengeluaran pemerintah serta net ekspor akan meningkatkan pertumbuhan ekonomi Indonesia. Sebaliknya, pertumbuhan ekonomi akan menurun jika terjadi penurunan konsumsi, investasi, pengeluaran pemerintah serta net ekspor (Ernita, Amar, and Sofyan 2013).

Regulasi baru perbankan atas kebijakan yang diambil oleh pemerintah telah memaksa perbankan untuk melakukan restrukturisasi kredit atau pembiayaan. Jika kebijakan ini dilakukan dengan konsisten, pemerintah akan mampu mempertahankan tingkat konsumsi masyarakat sehingga dapat mencegah penurunan ekstrem dari konsumsi masyarakat. Apabila semua dapat berjalan dengan baik, regulasi tersebut akan menopang pertumbuhan ekonomi Indonesia.

Dari sudut pandang mikro, debitur juga perlu diberikan pengetahuan untuk tidak mengambil kredit atau pembiayaan lebih dari $40 \%$ dari penghasilan mereka. Idealnya rasio utang terhadap penghasilan adalah berada di kisaran 15-20\% dari penghasilan (Tamanni and Mukhlisin 2018). Rasio ini perlu diterapkan agar ketika terjadi keadaan yang tidak diinginkan seperti Pandemi Covid-19, debitur tersebut tidak mengalami kesulitan yang berarti. Debitur hanya perlu sedikit penyesuaian terhadap pengeluaranpengeluaran yang lain akibat penurunan penghasilan yang dialami. Selain itu, diperlukan edukasi untuk tidak mengambil kredit ribawi dari bank konvensional karena perbuatan tersebut adalah dilarang dalam Islam. Apalagi masyarakat masih banyak yang menganggap sama antara kredit dari bank konvensional dengan pembiayaan dari bank syariah. Meskipun sekilas mirip yaitu debitur sama-sama harus membayar kelebihan atas nominal kredit atau pembiayaan yang didapat, pembiayaan dari bank syariah dibolehkan karena menggunakan akad yang halal seperti jual beli atau murabahah.

\section{Simpulan}

Alquran surat Al Baqarah ayat 280 telah memberikan solusi keuangan kepada kreditur untuk memberi kelonggaran kepada debitur yang terdampak Covid-19. Ayat ini telah dijabarkan kedalam peraturan formal di Indonesia yaitu UU Nomor 2 Tahun 2020 dan POJK Nomor 11/POJK.03/2020. Kedua peraturan tersebut merupakan landasan P-ISSN : 2460-9595 
hukum bagi perbankan untuk memberikan restrukturisasi kredit atau pembiayaan kepada debitur yang terdampak pandemi Covid-19. Restrukturisasi kredit atau pembiayaan perlu diberikan agar tingkat konsumsi masyarakat terjaga dan tidak mengalami penurunan yang besar. Ketika tingkat konsumsi dapat dipertahankan, maka pertumbuhan ekonomi juga dapat dipertahankan pada tingkatan yang optimal. Namun, peraturan tersebut tidak cukup jika pelaksanaan di lapangan tidak sesuai dengan apa yang sudah dicanangkan. Oleh karena itu, Pemerintah harus hadir langsung untuk memantau pelaksanaan dari aturan yang telah dibuatnya.

\section{DAFTAR PUSTAKA}

Ab Rahim, Nik Mohd Zaim, Ishak Suliaman, and Munirah Abd Razzak. 2012.

"Kesempitan Hidup Penghutang: Analisis Ayat 280 Surah Al- Baqarah.” In Annual International Qur'anic Conference, 114-26.

Aji, RHS. 2014. "Efesiensi Persaingan Bank Umum Syariah : Pendekatan Data Envelopment Analysis ( DEA ) Dan Boston Consulting Group ( BCG ).” Signifikan 3 (1): 63-80.

Aji, RHS, \& Kurniasih. 2015. "The Intelektual Capital Effect On Financial Performances At Islamic Insurance.” Al_Iqtishad 7 (2): 181-96.

Al-Qurtubi, Muhammad Al-Ansari Al. 2006. Al-Jami'li Ahkam Al-Qur'an Jilid 4. Beirut: Dar al-Risalah.

Bisnis.com. 2020a. "Pro-Kontra Keringanan Kredit Dari Kacamata Pelaku UMKM Dan Bankir - Finansial Bisnis.Com.” April 2020.

_. 2020b. "Keringanan Kredit Bank Capai Rp391,178 Triliun, Masih 30,67

Persen Dari Potensi Restrukturisasi - Finansial Bisnis.Com.” May 2020.

CNBC. 2020. "Pusingnya Pengusaha, Minta Keringanan Kredit Dicuekin Bank.” April 2020.

Ernita, Dewi, Syamsul Amar, \& Efrizal Sofyan. 2013. “Analisis Pertumbuhan Ekonomi, Investasi, Dan Konsumsi Di Indonesia.” Jurnal Kajian Ekonomi I (02): 176-93.

Kaminsky, Graciela L., Carmen M. Reinhart, and Carlos A. Végh. 2004. "When It P-ISSN : 2460-9595 
14 | Muhammad Ubaidillah, Rizqon Halal Syah Aji, TINJAUAN ATAS IMPLEMENTASI PERPANJANGAN...... Rains, It Pours: Procyclical Capital Flows and Macroeconomic Policies.” NBER Macroeconomics Annual 19 (January): 11-53.

https://doi.org/10.1086/ma.19.3585327.

Katsir, Ibnu. 2004. Tafsir Ibnu Katsir, Terj. Jilid 1. Bogor: Pustaka Imam Asy-Syafi'’i. Kompas. 2020. "Relaksasi Kredit Di Tengah Wabah Corona, Apa Betul Bikin Rileks? JEO Kompas.Com.” April 2020.

Kumparan. 2020. “OJK: WFH Hambat Perbankan Verifikasi Permohonan Keringanan Kredit - Kumparan.Com.” May 2020.

Nurhayati, Titik \& Aji, RHS. 2020. "Emansipasi Melawan Pandemi Global: Bukti Dari Indonesia.” Buletin 'Adalah, 2020. https://doi.org/10.15408/adalah.v4i1.15468.

Otoritas Jasa Keuangan. 2020. Peraturan OJK Nomor 11/POJK.03/2020 Tentang Stimulus Perekonomian Nasional Sebagai Countercyclical Dampak Penyebaran

Coronavirus Disease 2019. Menteri Hukum Dan Hak Asasi Manusia Republik Indonesia.

Rahim, NMZ Ab, I Suliaman, and M Abd Razzak. 2012. "Kesempitan Hidup Penghutang: Analisis Ayat 280 Surah Al-Baqarah.” In The 2nd Annual International Qur'anic Conference 2012, 114-26.

Republik Indonesia. 2020. Undang-Undang Republik Indonesia Nomor 2 Tahun 2020

Tentang Penetapan Peraturan Pemerintah Pengganti Undang-Undang Nomor 1

Tahun 2020 Menjadi Undang-Undang. Menteri Hukum Dan Hak Asasi Manusia

Republik Indonesia.

Sugiyono. 2012. Metode Penelitian Kombinasi. Pertama. Bandung: Penerbit Alfabeta. Sukirno, Sadono. 2011. Makroekonomi Teori Pengantar. 3rd ed. Jakarta: PT RajaGrafindo Persada.

Suryahadi, Asep, Ridho Al Izzati, and Daniel Suryadarma. 2020. "The Impact of COVID-19 Outbreak on Poverty : An Estimation for Indonesia The Impact of COVID-19 Outbreak on Poverty : An Estimation for Indonesia.” Jakarta.

Swaramarinda, Darma Rika, and Susi Indriani. 2011. "Pengaruh Pengeluaran Konsumsi Dan Investasi Pemerintah Terhadap Pertumbuhan Ekonomi Di Indonesia." EconoSains IX (2): 95-105. 
ISLAMIC BANKING: Jurnal Pemikiran dan Pengembangan Perbankan Syariah, Volume 6 Nomor 1 Edisi Agustus $2020 \mid \mathbf{1 5}$

Tamanni, Luqyan, and Murniati Mukhlisin. 2018. Sakinah Finance. Solo: Tinta Medina.

Tempo.co. 2020. “Dampak Corona, 3,05 Juta Orang Terkena PHK Hingga Juni - Bisnis Tempo.Co.” 2020.

World Health Organization. 2020. "WHO Coronavirus Disease (COVID-19)

Dashboard.” May 2020.

www.covid19.co.id 
16 | Muhammad Ubaidillah, Rizqon Halal Syah Aji, TINJAUAN ATAS IMPLEMENTASI PERPANJANGAN...... 